https://doi.org/10.31470/2706-7904-2021-16-313-316

\title{
ПРАКТИКА І ПЕРЕШКОДИ АУДІЮВАННЯ ПРИ НАВЧАННІ ІНОЗЕМНІЙ МОВІ В НТУ «ХПІ» У ХАРКОВІ
}

\section{Practice and Difficulties of Audio Classes in Teaching and Learning Foreign Languages at NTU «KhPI» in Kharkiv}

\section{Olena Shaposhnikova}

Senior Lecturer

National Technical University "Kharkiv Polytechnic Institute" (Ukraine)

elleonshaposh@gmail.com

\begin{abstract}
The analysis of listening as a type of language activity and the difficulties in listening practice while teaching English, German and French at National Technical University "Kharkiv Polytechnic Institute" are considered.
\end{abstract}

Key words: teaching, communication activity, listening, psychology.

\section{Вступ \\ Introduction}

Спілкування є основою комунікативної освіти. Це соціальний процес, у якому відбувається обмін досвідом, способами діяльності, вміннями та навичками, а також результатами діяльності. Комунікація є раціональною, емоційною та психологічною взаємодією людей, у процесі якої виявляється спільність або розбіжність думок (Пассов, 2000: 47).

Метою спілкування завжди є зміна відносин між людьми за участю психіки. Основними характеристиками спілкування $є$ ціль, результат, засоби та одиниці спілкування.

Способи спілкування можуть бути різними: перцептивний, інтерактивний, інформаційний та ін. (Коротицкая, 2007: 7).

\section{Методи та методики дослідження Methods and Techniques of the Research}

Аудіювання при навчанні іноземній мові є одним із засобів спілкування. Вони поділяються на вербальні та невербальні. До вербальних відносяться основні види 
мовної діяльності, яким навчають у процесі роботи з іноземною мовою. Це говоріння, писемна робота, аудіювання, читання. Міміка, жести, інтонація, темп, пози відносяться до невербальних засобів спілкування. Вони відіграють значно більшу роль у порівнянні з вербальними (Кибанов и др., 2002: 90).

Існують три аспекти мовних явищ: мова, мовлення і мовленнєва діяльність. Основні види мовної діяльності було виділено Л. В.Щербою, який вважав, що мовна діяльність - один із аспектів мови. Він розрізняв три аспекти мови: мову як процес говоріння та розуміння; мовлення як впорядкований лінгвістичний досвід, та мовленнєва діяльність і мовний матеріал, як невпорядкований лінгвістичний досвід (Щерба, 2003: 61).

Аудіювання, на відміну від говоріння, є рецептивним видом мовної діяльності. Форма його протікання внутрішня, невиражена. Вона впливає на психіку людини. Той, хто слухає, впливає на комунікацію: його реакція, наприклад, така, як сміх, репліки чи жести, викликають негайний вплив. На заняттях в НТУ «ХПІ» виявилося, що корисним є обговорення прослуханих тем або діалогів з можливим додаванням тих моментів, які викликали особливі труднощі або емоційний сплеск. Таким чином, аудіювання є реактивно - психологічним видом мовленнєвої діяльності.

Аудіювання - складний вид мовленнєвої діяльності, де процеси аудіювання в реальному спілкуванні не піддаються аналізу та фіксації. Нова інформація змінює стару, сказане безповоротно зникає. Часто не вистачає часу на обмірковування почутого, у зв'язку з чим розуміння часто не досягається і процес спілкування порушується. Перевантаження студентів надто складним матеріалом для аудіювання іноді призводить до психологічного неприйняття з боку студентів. Помічено на практиці, що студентам-іноземцям, які приїхали в Україну з африканських країн, аудіювання дається важче, ніж українським студентам.

У практиці викладання іноземних мов аудіювання тривалий час залишалося на периферії навчального процесу. Прогрес у цій галузі прийшов із появою високоякісної аудіоапаратури. При використанні сучасних можливостей Інтернету можна значно покращити якість аудіювання.

Першою групою труднощів аудіювання є проблеми, пов’язані з умовами сприйняття. Тут відіграють велику роль однократність і короткочасність пред'явлення інформації, що вимагає від слухача швидкої реакції при сприйнятті тексту, що звучить. Але ж, якщо студенти потребують повтору, слід задовольняти зацікавленість, аби досягти мети аудіювання.

Не менше значення має темп, що задається людиною, яка говорить. При цьому темп говоріння залежить і від конкретної мови. 
Труднощі при аудіюванні нерідко пов'язані і 3 джерелом аудіювання (або живий партнер у процесі безпосереднього контакту, або мова 3 аудіозапису, телепередачі або радіопередачі). Мають значення перешкоди, тембр, сила голосу, індивідуальні характеристики мови, відхилення від ідіоматичної чи нормативної вимови. Для розуміння має значення стать люди, яка говорить. (чоловічий чи жіночий голос), i, навіть, вік (дитячий чи дорослий голос). Відомо, що розуміння дитячих голосів потребує певних навичок. У реальному спілкуванні неможливо регулювати тривалість, гучність і чистоту звучання тексту, тому слухач може швидко втомлюватися і його увага розсіюватися. А це, своєю чергою, веде до втрати зацікавленості, вбиває мотивацію подальшої роботи з аудіотекстом (Филатов, 2004: 239).

Наступна група труднощів пов'язана зі сприйняттям мовної форми та змістовним наповненням аудіотексту. Мовні труднощі тексту відволікають тих, хто слухає зміст, і процес розуміння порушується. Істотну роль відіграє довжина сприйманих слухачем речень, наявність незнайомого лексичного, граматичного мовного матеріалу, присутність в інформації слів, що однаково звучать, але різних за значенням, або слів, що однаково звучать, але мають різне написання. Існують також звані «хибні друзі перекладача», інтернаціоналізми, які мають інше значення іноземною мовою. Іноді слова вживаються в переносному значенні, зустрічаються багатозначні слова, і т. д.

Можна зустріти труднощі, які відносяться до змісту аудіотексту, пов'язані 3 розумінням фактів - цифр, дат, власних назв, географічних назв, з розумінням логіки викладу, з великою кількістю фактичної інформації, а також із загальною складністю ідеї тексту. В таких випадках ми попереджуємо про складнощі через спеціальні вправи і обговорення.

Подальша група труднощів пов'язана з формою пред'явлення аудіотексту.

Барбара Дальгаус (Dahlhaus, 2007: 66) вивчила різні форми пред’явлення аудіотекстів: аудіотекст з ілюстрацією; аудіювання з опорою на друкований текст, аудіювання без опори при пред'явленні аудіотексту; одноразове пред’явлення; багаторазове пред'явлення тексту.

Вона вважає, що розуміння тексту на слух залежить від таких факторів, як складність тексту (що складніше текст, тим більше опор потрібно для зняття труднощів), мовний досвід учнів (чим компетентніші і досвідченіші учні, тим швидше вони здатні відмовитися від опори у вигляді друкованого тексту та інших ілюстрацій).

3 початку навчання вчитель повинен пам'ятати, що він готує учнів до реальної ситуації спілкування, тому опори слід зменшувати, готувати учнів, наприклад, до розуміння тексту без повторного прослуховування. 
Існують труднощі, пов’язані зі сприйняттям певного виду мовної діяльності та типу висловлювання. Вочевидь, що легше сприймати монологічні тексти, ніж діалогічні, а серед монологічних простіше сприймати фабульні тексти, ніж описові.

Особливу групу складають труднощі, пов'язані із соціокультурною складовою навчання іноземним мовам. Незнання соціокультурних особливостей може призвести до нерозуміння мовної поведінки партнера, i, навіть, порушити розуміння інформації, яка сприймається на слух.

\section{Результати \\ Results}

Організація навчання іноземній мові потребує включення аудіювання як обов’язкової складової частини в кожне заняття, і така практика дає дуже позитивний результат. Наприклад, першокурсники економічних спеціальностей за перший семестр 2020/2021 навчального року покращили рівень результативності аудіювання, перевірений тестами, в середньому $350 \%$ до 75\%. Студенти комп'ютерних спеціальностей виявили аналогічний результат: підвищення результативності аудіювання з 60\% до 80\%, а деякі групи показали $100 \%$.

\section{Висновки \\ Conclusions}

Студенти НТУ «ХПІ» у Харкові займаються аудіюванням по прогресивним світовим методикам і підручникам, які мають аудіо супроводження для класних, домашніх та тестових завдань і орієнтовані на галузь науки, яку ці студенти вивчають.

\section{Література \\ References}

Пассов, Е.И. (2000). Программа-концепция иноязычного образования. Конщепщчия развития индивидуальности в диалоге культур. 5-11 классыл. Москва.

Коротицкая, М.В. (2007). Коммуникативная культура организации. Автореферат дисс. канд. сочиол. наук. Москва.

Кибанов, А.Я., Захаров Д.К., \& Коновалова, В.Г. (2002). Этика деловых отношений. Москва: ИНФРА-М.

Щерба, Л.В. (2003). Преподавание языков в школе: Общие вопросы методики. (3-е изд., испр. и доп.). Москва.

Филатов, В.М. (Ред.). (2004). Методика обучения иностранным языкам в начальной и основной общеобразовательной школе. Ростов-на-Дону.

Dahlhaus, B. (2007). Fernstudieneinheit 5. Fertigkeit Hören. Berlin. 